\title{
Developing transformational leadership for sub- Saharan Africa: Essential missiological considerations for church workers
}

\begin{tabular}{|c|c|}
\hline \multicolumn{2}{|c|}{$\begin{array}{l}\text { Authors: } \\
\text { Kalemba Mwambazambi }{ }^{1} \\
\text { Albert K. Banza }{ }^{2}\end{array}$} \\
\hline \multicolumn{2}{|c|}{$\begin{array}{l}\text { Affiliations: } \\
{ }^{1} \text { Department of Practical } \\
\text { Theology and Missiology, } \\
\text { University of Stellenbosch, } \\
\text { South Africa }\end{array}$} \\
\hline \multicolumn{2}{|c|}{$\begin{array}{l}{ }^{2} \text { Department of Church } \\
\text { History, Spirituality and } \\
\text { Missiology, University of } \\
\text { South Africa, South Africa }\end{array}$} \\
\hline \multicolumn{2}{|c|}{$\begin{array}{l}\text { Correspondence to: } \\
\text { Kalemba Mwambazambi }\end{array}$} \\
\hline \multicolumn{2}{|c|}{$\begin{array}{l}\text { Email: } \\
\text { profkalemba@yahoo.fr }\end{array}$} \\
\hline \multicolumn{2}{|c|}{$\begin{array}{l}\text { Postal address: } \\
\text { Private Bag X1, Matieland } \\
7602 \text {, South Africa }\end{array}$} \\
\hline \multicolumn{2}{|c|}{$\begin{array}{l}\text { Dates: } \\
\text { Received: } 11 \text { Mar. } 2013 \\
\text { Accepted: } 01 \text { Aug. } 2013 \\
\text { Published: } 28 \text { Feb. } 2014\end{array}$} \\
\hline \multicolumn{2}{|c|}{$\begin{array}{l}\text { How to cite this article: } \\
\text { Mwambazambi, K. \& Banza, } \\
\text { A.K., 2014, 'Developing } \\
\text { transformational leadership } \\
\text { for sub-Saharan Africa: } \\
\text { Essential missiological } \\
\text { considerations for church } \\
\text { workers', Verbum et Ecclesia } \\
\text { 35(1), Art. \#849, } 9 \text { pages. } \\
\text { http://dx.doi.org/10.4102/ } \\
\text { ve.v35i1.849 }\end{array}$} \\
\hline \multicolumn{2}{|c|}{$\begin{array}{l}\text { Copyright: } \\
\text { C 2014. The Authors. } \\
\text { Licensee: AOSIS } \\
\text { OpenJournals. This w } \\
\text { is licensed under the } \\
\text { Creative Commons } \\
\text { Attribution License. }\end{array}$} \\
\hline \multicolumn{2}{|l|}{ Read online: } \\
\hline 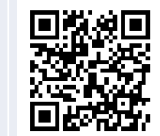 & $\begin{array}{l}\text { Scan this QR } \\
\text { code with your } \\
\text { smart phone or } \\
\text { mobile device } \\
\text { to read online. }\end{array}$ \\
\hline
\end{tabular}

Authors:

alemba Mwambazambir

Affiliations:

${ }^{1}$ Department of Practical

Theology and Missiology, University of Stellenbosch,

${ }^{2}$ Department of Church History, Spirituality and Missiology, University of

\section{Correspondence to:}

Email:

Postal address:

Private Bag X1, Matieland

\section{Dates:}

How to cite this article: Mwambazambi, K. \& Banza, A.K., 2014, 'Developing transformational leadership for sub-Saharan Africa: Essential missiological workers', Verbum et Ecclesia 35(1), Art. \#849, 9 pages. http://dx.doi.org/10.4102/ ve.v35i1.849

\section{Copyright:}

(C) 2014. The Authors. Licensee: AOSIS is licensed under the Creative Commons Attribution License.
Aware of the particular importance of efficient leadership for Africa, this article investigates how Africans can develop the kind of leadership their continent needs to contribute to effective transformation. Therefore, essential notions and procedures are analysed and described; the meaning and qualities of transformational leadership that can effect solid transformation of both individuals and their communities are explained. Lack of theoretical and practical understanding of effective leadership, colonial history of the continent, inappropriate spirituality amongst post-colonial Africans, poor ethical role-modelling in African communities, and poor awareness of the need for effective leadership development are amongst the main causes of poor leadership in African communities. So, developing efficacious transformational leadership for Africa requires that the causes of poor leadership be removed. Subsequently, the flourishing of the strong moral and socio-political qualities necessary for solid transformational leadership equally demands an intentional work.

\section{Introduction}

Transformational leaders are those who generally observe principles of human dignity and worth, human rights, good social values, and individual and socio-political transformation; such leaders are able to recognise and enhance existing needs or demands of potential followers, as suggested by Burns (1978:4). The issue of leadership is a very important one, because individual and sociopolitical success depends on whether good or bad leadership is exercised. Supportively, Maxwell (2007) observes:

I wholeheartedly believe that everything rises and falls on leadership. By that I mean that, more than anything else, the leadership of any group or organisation will determine its success or failure. (pp. v-vi)

The concern for leadership that can contribute to the transformation of the African continent is even more important; such leadership can contribute to human and economic development, to resolution of rampant conflicts, and to socio-political transformation. Rotberg (2004:9) suggests that especially because of weak economies and weak institutions in Africa, the problem of a lack of transformational leadership matters more for this continent than for other parts of the world.

The issue of effective transformational leadership for Africa is crucial, not only for the present but also for the future of the continent. Given the importance of transformational leadership, it is essential to step beyond mere discussions on leadership theories and assessment and start exploring how to develop the necessary leadership for the continent. Commenting on the urgency of developing the required leadership, Linthicum (1991:93) insists: 'Without leadership development, everything you have done will pass away. But with it, the future is constantly being created anew for the people of your community.' Therefore, to develop such leadership this article aims to answer the following questions:

- What specific leadership is needed?

- Which factors would be considered in the development of such leadership?

- What kind of people can qualify for the effective development of the necessary leadership?

This article proceeds to discuss (1) transformational leadership and qualities required for such leadership, (2) re-education of African leadership and their re-spiritualisation, re-socialising and re-Africanising Africans, (3) restoration of Africans psychologically and their preparation for further decolonisation and prevention of re-colonisation. All of the above are important aspects of the training programme aimed at efficient development of transformational leaders for the continent.

An analytic and descriptive methodology is used in this article. Key terms and essential notions are described and explained. This article emphasises the personality and character of leadership 
facilitators or developers, since personal transformation and self-leadership of any person is essential for the individual and communal good. A careful consideration of these elements in the development of sub-Saharan African leaders allows the removal of causes of poor leadership and a pleasurable enjoyment of effective leadership in the continent.

\section{Research background and development}

Much of sub-Saharan Africa has been politically independent for the last 50 years. However, most of the nations of the continent have been facing issues of persistent dictatorship, poverty, corruption, selfishness, exploitation, tribalism, social injustices, neo-colonialism and aimless armed conflicts - challenges that urgently call for transformational leadership in order to bring about effective transformation. The problem of unethical and exploitative sub-Saharan African leadership has been compounded and sustained by neo-colonial support to this leadership, poor self leadership models of African leaders (Mentan 2007:210) and lack of referral terms of efficient leadership development (Gordon 2002:13).

Mathafena (2007:29-30) explains development as an act or a process of developing a gradual and unfolding growth in an individual. She then remarks that the development of people refers to the advancement, skills, competencies, and the improved behaviour of people within the organisation for their personal and professional use. Therefore, this article aims to carefully consider the causes of poor leadership in the continent to combat those and develop a kind of leadership with the required qualities, so that the leaders can be sufficiently efficient both in developing more transformational leaders and in effecting the needed transformation in their communities. Lack of knowledge and understanding of what is effective leadership for the transformation of this continent - especially ignorance of what such leadership means in theory and practice - is one of the main causes of poor leadership in Africa. Such damaging ignorance requires seminal theoretical and practical training on leadership that can contribute to transformation. Consequences of the sub-Saharan African history of slavery, oppression and colonisation which have continued to negatively influence Africans ethically, psychologically and socio-politically are also considered in this article. These considerations include curriculum components, the character of the trainer and the needed environment for effective results in the development of the required African leadership. Van Rensburg (2007) emphasises:

The idea that we can develop as leaders in isolation is an illusion. The African principle of ubuntu and community is highly relevant to leadership. We cannot separate our desire to be affirmed and to be in the position to affirm others. (p. 89)

\section{Transformational leadership}

A clear understanding of what transformational leadership for the African continent consists of, is an important factor of leadership development, because it affords the exact knowledge of the concept and the qualities required of both the trainer and the trainee and the necessary social context for effective results. Such understanding can also encompass and suggest the first elements of the training programme, which can be used for the development of the leaders and how to use those elements for reliable results. A transformational leader is one able to recognise and enhance an existing need or demand of a potential follower. Describing this type of leadership, Burns (1978:4) observes that the leader looks for potential motives in the followers, seeks to satisfy higher needs, and engages the full person of the follower. The result is a relationship of mutual stimulation and elevation that converts followers into leaders and may convert leaders into moral agents. Explaining later what moral transforming leadership amounts to, he proceeds saying:

Transforming leadership becomes 'moral' in that it raises the level of human conduct and ethical aspiration of both the leaders and the led, and thus it has a transforming effect on both. Perhaps the best modern example is Gandhi, who aroused and elevated the hopes and demands of millions of Indians and whose life and responsibility were enhanced in the process. (p. 20)

A transformational leader is a leader who understands his or her moral responsibility as that of contributing to the transformation and enhancement of individuals and communities or organisations for a higher communal good. Mathafena (2007:75) puts it like this: 'Transformational leaders transform followers by creating changes in their goals, values, beliefs and aspirations.' Commenting then on their behaviour, action, role and influence she emphasises that these leaders behave according to transformational leadership principles and hence become admired role models who are respected, emulated and trusted. One of the key things a leader does to earn credibility is the consideration of the needs of others over his or her personal needs. Leaders share risks with followers and are consistent rather than arbitrary; they can be counted on to do the right thing, demonstrating high standards of ethical and moral conduct; they avoid using power for personal gain - and then only when needed. Leaders behave in ways that motivate and inspire those around them by providing meaning and challenge to their followers' work. Team spirit is aroused, enthusiasm and optimism are displayed.

Leaders get followers involved in envisioning attractive future states. Mathafena equally posits that transformational leaders engender trust, seek to develop leadership in others, exhibit self-sacrifice and serve as moral agents, focusing their attention and that of their followers on objectives that transcend the more immediate needs of work groups. Transformational leadership can produce significant organisational change and results, because this form of leadership fosters higher levels of intrinsic motivation, trust, commitment, and loyalty from followers than do most leadership practices. Speaking of the evaluation of this leadership, Mathafena (2007) states:

Transformational leadership is measured by both the leader's performance and development, and by the degree to which associates are developed to their full leadership potential. The associates are encouraged to use the techniques of effective leadership. (pp. 74-75) 


\section{Transformational leadership qualities}

The specific qualities of transformational leadership are able to achieve the needed transformation on the African continent at various levels. Van Rensburg (2007:88) observes that if we understand leadership to be transforming situations, environments and organisations to a more desired state, then the question is: 'What are the essential qualities in a leader that enable him or her to influence others in such a way that they collectively contribute to transformation?' As mentioned above, transformational leaders generally look beyond their personal achievements. They are not intent on using their power or influence to make themselves look good. Walters (1987:11, 13, 40,48) and Greenleaf (2002:240) argue that the essence of leadership is to focus on the needs of others and then apply one's talents, technical, rational, and emotional as well as one's visualising abilities to address those needs. Leaders see themselves as catalysts and facilitators in the creation of something that is only possible with collective effort and the talents of diverse people, something that represents further possibilities for growth.

The focus of their approach is to facilitate the process where a growing number of members have internalised shared values that motivate their contributions. That way people motivate themselves and the relationship with the leader become interdependent and not dependent. It furthermore implies the leader's willingness to enable and to empower others (Van Rensburg 2007:67). Transformational leadership is therefore a kind of leadership that is selfless and ethical in intent, in behaviour and in action. A transformational leader uses his or her own skills, qualities and values as well as those of others to positively influence the lives of the followers who, in turn, grow into solid transformational leaders capable of transforming individuals, organisations and communities.

\section{Appropriate context for the development of a transformational leadership for Africa}

Leaders can be developed from different contexts, such as family, school, college or university, and church. It can be done in Africa or abroad. This article, however, focuses on the contribution church leaders can make by sensitising Africans to real transformation for reliable leadership. Working for and with the surrounding communities whilst keeping an open eye to global issues that affect and influence them both positively and/or negatively, African churches through their leaders can achieve a lot. Such sensitisation and empowering of Africans is essential as it focuses on the development of the required values for the necessary leadership that brings about community transformation. Many alienated African masses can also be taken on board whilst their leaders are helped to reconnect with them and learn to serve them with dignity. Such a project can be effective and of real value only when it is fully aware of the time, context and real needs of the continent as part of the global village.

Contributing to the development of the required leadership from within the very community that needs the leaders will demand church leaders to know their church members who can contribute to leadership development and who can also effectively use their expertise for this purpose. They will equally need to understand community potential and problems as well as cultural issues which can create unnecessary clashes. Van der Walt (2001:103) qualifies African Christianity as being escapist, since African Christians often run from socio-political realities; their involvement to solve socio-political problems can rid the church of such escapism. Various social groupings of the community can also be informed and educated about acceptable and unacceptable leadership issues. They should be educated about current socio-political realities in order to fully understand the situation in which they live so as to be able to act and respond to any socio-political situation in a responsible fashion. Supporting the education and implication of the whole community for sustainable solution to real community problems, Mbeki (2003) alleges:

One of these is that we should treat the critical matter of Africa's development and reconstruction as a challenge that faces not only our government and the African elite, but also the masses of our people. Accordingly, we must seek to ensure that whatever we say as Africa's intelligentsia and leadership, we communicate this to ordinary people of our continent. Thus should they be empowered to speak out about what they want for themselves, their countries and continent. And thus will they be enabled to participate in the struggle to emancipate themselves from poverty, underdevelopment and despair. (p. 101)

Amongst other things, this quote suggests that the space is available for the education of everyone to enable all to contribute in an effective way. Since African churches are the most powerful societal structures in sub-Saharan Africa (Gifford 1998:1), their contribution can be the most effective. A wide spectrum of suggestions from different fields of human activities can be used to reach effective development of the needed leadership. Contributions from education, psychology, anthropology and any other field of study can make a difference, where necessary. For example, Mogo (1999) suggests:

Further, education for sustainable development will have to inculcate an ethos that shuns personal aggrandizement, which is epitomized by senseless individualistic accumulation of wealth at the expense of the majority. (p. 227)

In the same vein, speaking of the education of people who have lost their self-esteem, as most Africans have, in one way or another, Hoppers, Moja and Mda (1999) observe:

When you deal with people who have lost their self-esteem, their pride as well as their dignity, it is important that the 'knowledge' fed to them is fused with a sense and objective of helping them regain that which they have lost. (p. 233)

Theorising on how to develop ethical African citizens, transformed people who can qualify as moral agents or servants and as transformational leaders according to the African traditional communalism model in today's Africa, Ramasamy (2004) posits that to deal effectively with past Western destruction of the precious values in today's context of science and technology - where we recognise that there is 
also room for personal thought and decision-making serving scientific development and community welfare - we cannot only condemn the evils of the Western education but also appreciate its positive side. Whilst destroying, supposedly, the precious African values, this education also opened Africans to the world of science and technology, and to learning much wider than what was known to them up to that time. It must also be understood that both individual thinking and action and communal thought and action have their place in today's context. If everybody only learns how to think like everybody else in everything, there is little room for independent thinking, which can lead to slavish thinking and action. Consequently, scientific development, creativity, transformation can easily suffer from it.

Proceeding further, Ramasamy (2004) argues that it must be understood that both individualism and communalism have their own particular strengths and weaknesses. Communalism can lead to conformity and conservatism, which could lead to slavishly following the norms of a society without questioning anything. Certain individuals can be treated unjustly, for example, for many an individual has suffered because of communal practices such as female genital mutilation and the like. In addition, there is no norm for creative thought and initiative in such a context. Individualism, on the other hand, allows one to take full responsibility for oneself. Individual initiative is encouraged and a person can fulfil his or her full potential in life. Many great religious revivals and even non-religious movements were led by great individuals who could think for themselves. Individuals who were not enslaved by traditional or communal norms have contributed to advances in the fields of science, technology and medicine (Ramasamy 2004:101). Individualismcan, however, also lead to selfishness.

Operating from within the African communities that need transformational leaders for socio-political transformation, the work of leadership development can be informed with the needed precision. It can also help whilst learning from community people to educate them according to the real needs of their time and in light of the global situation. Community people can also be educated about the development of transformational leaders from their families and community organisations, about how to discern and combat poor leadership and how to prepare for anti-recolonisation. Developing leaders from within the community contributes to helping them to understand real needs of the people so as to be able to respect them, work with them and serve them effectively.

Interaction with African communities can successfully lead to the development of solid transformational leadership for Africa from outside the church arena. But sometimes better results can be reached when working seriously with Africans who are church members so that their transformation can positively affect the lives of many others, as explained by Gifford (1998:346) who wrote about the role and influence of the Korean Church on Korean life and society.

\section{Transformational leadership facilitator or developer}

People who develop training materials and programmes, and especially those who apply them, are essential contributors to the real transformation of potential leaders, as they are directly involved in the development of leaders for sociopolitical transformation. Their prior transformation, character or self-leadership plays a key role in the transformation and the necessary development of others. De Beer and Venter (1998) argue that:

the missionary, minister or Christian worker must be transformed as well as the church or organisation and as these individuals and groups experience transformation, they will also be able to facilitate the transformation of their communities. (p. 33)

Given that these church leaders are expected to further the development of transformational qualities in other people, their own transformational qualities should include a vast range of character traits and abilities. Those include, for example, transformative, spiritual, psychological and social character traits, such as integrity, proposed by Prozesky (1990:138) and Van Rensburg (2007:95), unconditional love and consideration for the underdog, proposed by Smith (1996:40-41) and intercession readiness for people in authority, after Halverson (1982:23). These transformed church leaders may also be able to practise transformative theologies (Kretzschmar 2006:352). Moreover, they do not suffer from social psychopathologies (Fanon 1967:125). Their personal experience with a four-dimensional discipleship (Banza 2003:54-58), strong Christian character (Thomson 1996:45), proactivity and conflict management abilities (Smith 1996:64) are also essential.

Speaking of the cosy church-state relationship in some African countries, especially in Cameroon, Gifford (1998:307) remarks: 'These attitudes are at least partly shared by the church elite, and many churches, too, are characterised by "la politique du ventre".' Instead of serving the people, they often use their church positions and/or positions in the society to serve themselves whilst causing the suffering of many. Serious moral defects are simply unacceptable for any person who plays a role in the development of transformational leaders because these prevent one from modelling effective moral leadership. Transformational leadership developers or facilitators are expected to provide leadership from the front by their personal self-leadership and role-modelling (Walters 1987:13). Maxwell (2007:1118) observes: 'Leaders cannot give what they do not have.' Commenting on the development of good character and discipline in the lives of others, Mbigi (2005) maintains:

Learning to be involves being able to develop character and discipline, and this aspect is often neglected in current leadership programmes. Many leadership programmes emphasise managing others instead of managing one self, and throughout history self-management has been the distinguishing work of geniuses in every walk of life. Any obstacle to success in life can be overcome, but if you yourself are the obstacle then nothing can be done to remove the constraint. (p. 145) 
The quote stresses the urgency of the transformation of the leader before getting involved in seeking the transformation of others. For it is hard for one to adequately assess the value of what they have never experienced. It equally emphasises the risk that church leaders and other people involved in leadership development run if they lose sight of the priority of personal transformation before designing effective transformative programmes and projects for the transformation of their people, nations and communities, especially that of leaders.

Mbigi (2005), as cited above, does not speak specifically of Christian leadership. It can, however, be observed that when it comes to solving a socio-political problem or a problem of autocratic and bad leadership in the community, Christians sometimes prove so ungodly and highly academic-minded that they forget the action of the Almighty God who asks them to pray for the peace of their communities and the transformation of their leaders as suggested in Jeremiah 29:7 and 1 Timothy 2:1-4, for example. Almost unsure of the power of God, Christians sometimes rush into writing projects and elaborating programmes for others whilst forgetting their own state, especially the ethical state of their leaders. The suggestion here is not that Christians do not have to write projects. On the contrary, they should write them because those who work for the impoverishment of peoples and of their communities, for environmental and human destruction (Perkins 2004:ix-xxi) also plan and often use pernicious powers (Renou 2001:421-422), to act very destructively. But it is essential that before writing projects, Christians must first consider their own spiritual state and pray.

\section{Transformational leadership education}

Transformational leadership education is crucial training for effective leadership development, which can encapsulate both theoretic and practical aspects. This education can be geared at combating ignorance and providing people and especially leaders with the needed knowledge and skills. Van Rensburg (2007:87-88) insists that the standards and effectiveness of education in all areas of life are crucial to the development of leaders who will be able to face the challenges of today's world'. The programme can encapsulate aspects of the history of Africa, leadership in Africa and/or specifically in traditional Africa where people can be educated on the values and mistakes of the past and how moral education and leadership development were carried out and sociopolitical challenges dealt with. It can also emphasise why and how challenges in today's Africa can be interpreted and handled differently.

One of the proposals to be considered here is that of the Ciulla's curriculum. Ciulla (1996:193) describes Jepson School as a school in progress. The school was first opened in America to educate people for and about leadership. The mission was to prepare students to take on the moral responsibilities for leadership. A comprehensive leadership development was envisioned; aspects of leadership whether in business, government, communities, or social movements, as service to society were all dealt with. This school presents constructive programme courses. The core courses in the 2-year programme are History, Theories of Leaders, Critical Thinking, Leading Groups, Ethics and Leadership. The other elements of the Jepson School leadership programme are a list of competency courses such as conflict resolution, decision making and policy making (Ciulla 1996:193-195).

Some of the subjects offered in this school such as Ethics, History, Theories of Leadership which can also include, Critical Thinking, Leading Groups, Courses on Conflict Prevention and Resolution, Decision Making, Policy Making, Political Leadership, Community Leadership, Social Movement Leadership, Organisation Leadership, Business Leadership and Government Leadership also stand out as of special interest for leadership development. Offering ethical education to African leaders would equip them with a system of moral principles that would help them to behave and run the business of their communities and nations in a sensible and effective way as indicated by Kä Mäna (2005:211-212).

African History education would make them more knowledgeable of where the continent is coming from and where it is now, inform their thinking and decisionmaking, empowering them thus for efficient planning and implementing of their socio-political and national programmes as postulated by Okumu (2002:71) and Mbeki (1998:99). Leadership theories would equip leaders with full understanding of who and what is a leader; of what are the responsibilities of a leader to be able to work purposefully, being entirely focused on the intended objectives. Courses on community leadership, social movement leadership and leadership groups would make leaders into strategic transcultural leaders able to cross socio-political barriers and thus inspire multicultural dynamics whilst honouring the individual cultures represented in the community as shown by Williams (2006:iv). Courses on conflict prevention and resolution would empower them with special abilities to prevent many socio-political conflicts in the African communities and, in case of a conflict that is already in process, they would be able to manage it skilfully (Banza 2003:109).

Although such training programmes can better be accommodated and carried out by academic institutions or organisations with or working with schools than ordinary churches, churches can also use some of their elements in different church activities. For example, when exhorting Christians before praying for leaders or for socio-political transformation, an aspect of the history of their people can be explained, so that they can receive education about that specific aspect. Sometimes, when launching a psychotherapeutic activity in the community, a church organisation that is in charge of that activity can carry out some history education. When working for socio-political or moral conversion, ethical education can be realised. 


\section{Re-spiritualising African leaders}

Spirituality is an important aspect of leadership which also determines whether someone's leadership is good or bad. Accordingly, Wellman, Perkins and Wellman (2009:1) suggest: 'Leadership theorists posit that spirituality is the core of effective leadership that guides behaviors and interactions with others ...' Explaining what it can amount to Mihai (2009:1) observes: 'Spirituality, therefore, is more about how people identify themselves, how they view the world, interact with others, and make decisions.' Spiritual leaders in a workplace are consequently expected to encourage and inspire employees to find meaning and purpose in their lives, to demonstrate empathy, show integrity, honesty, kindness, and respect in dealing with others, and to value the wellbeing of others above their own interests.

They are also expected to live by example, be socially and environmentally responsible, be ethical and moral, have a certain degree of humbleness, aim to serve and inspire others, promote leadership based on respect and love, not fear. Down on the same page the author describes the leaders who are not spiritual as follows: 'They not only lacked honour, compassion, and responsibility towards others, but as fear-based leaders, they were also known for destruction and lack of respect for mankind in general.' Spirituality should be dissociated from religion because there are a lot of religious persons who are not spiritual whilst non-religious people prove highly spiritual in words, deeds, behaviours and attitude (Mihai 2009:1). The information as furnished by Mihai (2009) and Wellman et al. (2009) is essential here. A spirituality which fails to translate into good actions, attitudes and socio-political behaviours, especially in unconditional love, respect of others, particularly of the underdogs, needs revisiting for proper rectification.

Religiously speaking, spirituality and the personal relationship of leaders with their God play an important role as concerns their personality, behaviour, actions and attitudes towards individuals, especially underdogs, as well as towards the socio-political transformation of their communities. In his book, The Leadership challenge in Africa: A framework for African Renaissance leaders, Van Rensburg (2007:58) raises an interesting question about the importance of the spirituality of the leader in traditional Africa. He specifies that the leaders' relationship with God played a very important role. He then states:

The traditional African leaders were spiritually minded. The existence of God and the role that He played in providing the necessary protection, guidance and inspiration to their leadership, helped them to understand their primary responsibility from which they had to take care of their subjects and seek all means to create a conducive environment for everybody in the community. (p. 58)

Clearly, Van Rensburg speaks of the leaders who were faithful both to their God and religion; they would carefully learn the teachings of their religions, become transformed through the full observation of those doctrines. Personal transformation of a leader in his or her relationship with God conditions his or her understanding of the primary responsibility in the community and the way she or he behaves, acts, or reacts to people and situations. Gerhard van Rensburg speaks of the God the traditional Africans believed in before Christianity and even after that. However, his remark suggests something essential to the church, the larger community and the leaders about an aspect of the contribution they are supposed to make to the development of transformational leadership. It is true that 'spirituality' and a 'personal relation with God' are something one can hardly measure, but they remain a source of personal true commitment and transformation, which also conditions attitudes, behaviours and actions towards individuals and communities. Spirituality and a leader's personal relationship with God equally condition further personal transformation and that of many others.

Commenting on the personal transformation of King Josiah and the subsequent spiritual and socio-political transformation of his people in 2 Chronicles 34, Maxwell (2007:570) observes that over and over again in the history of Israel this pattern repeats itself. 'Low or high spirituality' of the leader means a lot for his or her people. So, given that the primary responsibility of the church is to make true disciples of Jesus Christ (Barna 2001:17-18), who can strive to live as light of the world and salt of the earth (Kalemba 2011:12), churches should do the utmost they can to help their members reach the highest spirituality possible. Africa is known as a very religious continent that has more than $96 \%$ of the population practising a given religion; Banda (2010:1) even specifies that Christianity is the most predominant religion in the continent representing $58 \%-68 \%$ of the believers. The contradiction seems too huge when very religious peoples have very undemocratic and poor leaders, a situation that may suggest something about the quality of the spirituality of their leadership. McDowell and Beliles (2008:91) assert: 'External political slavery reflects internal spiritual bondage.' Leaders in traditional Africa were the most democratic and caring ones, according to Gordon (2002:3). The same Gordon suggests later that the colonisation of the African continent and other foreign influences have impacted the current African leadership. Mulemfo (2001) insists that in traditional Africa:

If the ruler showed a clear tendency to 'exceeding his authority' or prospering while the rest of his society were poor and hungry, he was removed from office as unfit to rule. (p. 49)

Re-spiritualising African leaders would consist in helping them develop values which they can live out in their day-today life with their followers. Values of unconditional love, honesty, justice, respect, impartiality, caring, and service are some of those. Through their own ethical being, moral living, positive social attitudes and behaviours, church leaders can contribute greatly to the transformation of others. Wellman et al. (2009:1) conclude 'thus, an effective leadership model will include characteristics of being scholarly, practical, ethical, moral, just, caring, equitable, fair, and democratic ...' 


\section{Re-educating Africans for transformational leadership}

Colonial education and to an extent Christianity as brought to Africans seem to have played a dissocialising and deAfricanising role for many Africans, especially those who have been educated to serve Western interests in the continent. These institutions have influenced Africans to lose their spirit of communal solidarity and to become more individualistic in behaviour and lifestyle. Blaming colonisation of Africa, Ramasamy (2004:108) observes that Western colonialism, in partnership with Protestantism, promoted an individualistic ethic that disrupted the fundamental communal pattern of African social existence. He consequently suggests that there is a need to restore this order as it can harmonise with the African spirit of ubuntu. Senghor (1988:22) particularly criticises the Catholics, explaining that the greatest defect of the colonial education was the attempt to uproot Africans from their values. The priests who ran the schools tried to convince African pupils that their culture was worthless and that the French culture was more important than that of the Africans. They thus strove to cultivate an inferiority complex in the minds of the learners. Rodney (1982:248-252) insists that:

it can be said that among those who had the most education were to be found the most alienated Africans on the continent. It followed that those who were europeanised were to that extent de-Africanised, as a consequence of the colonial education and the general atmosphere of colonial life. (p. 252)

Describing the nature and consequence of this education on modern African education, Mbigi (2005) states:

Modern African education has its roots in colonialism, whose agenda was to exploit Africa, dehumanise its people and their culture, and destroy the positive self-image and self-confidence of the African people. (p. 139)

Europeanising was a major objective of the colonial education. Negative consequences of foreign negative influences, being still very impressive on the current socio-political life in the continent, demands that educative actions be taken to reAfricanise Africans assisting them to develop and adopt a social lifestyle of ubuntu, which depreciates selfishness and other anti-social and exploitive behaviours. From church viewpoint Mugambi (1995:52) advises:

The pulpit can become a central oral medium for transmission of new ideas and changing attitudes. During colonial period missionaries used the pulpit for undermining the cultural values of African peoples. In future, the same medium can become a viable instrument for restoration of the people's confidence, in the same way as it was during the reformation in Europe. (p. 253)

Positive aspects of the history of the continent can be underscored to boost self-confidence and further the development of social values in them. Insisting on the particular importance of this history, Mbigi (2005:79) observes: 'Without knowledge of history or his links to the past, man is a social amnesiac, both intellectually and therefore to some extent emotionally rootless.' This knowledge of history can equally help Africans to be actively aware of where they are coming from, where they are, and to be able to plan for where they should go and how to successfully reach the destination. Re-educating Africans would require comprehensive action carried out by people from various cultural and social domains. Psychologists, religious people, educationists, anthropologists, historians and any other organisations or individuals who can valuably contribute, can make their inputs. Both short and long term actions can be planned and revised as the needs arise. Closely related to re-education of the peoples of the continent is their psychological restoration.

\section{Restoring African leaders psychologically}

Psychological conditions of individuals or those of a whole community are important because they can influence people's lives, attitudes, behaviours, actions and their entire culture, either positively or negatively. Fanon (1967:228) observes that many Black Africans suffer from a hidden inferiority complex, subtle low self-esteem and self-mistrust. This complex is sometimes translated into a superiority complex and exploitative behaviours towards other Africans as a way of transcending to a higher rank or social stratum. Francis Fanon insists that this psychological condition is a legacy of colonisation which can have lingering negative effects at various levels. Therefore, Africans' psychological restoration consists in bringing about cultural and psychological catharsis, which can lead to the development of a new character, high self-esteem, improved self-leadership and the enjoyment of better behaviours, attitudes and actions. Informed by his expertise in leadership, African history and the consequences of slave trade, colonisation and neocolonisation, Van Rensburg (2007:61-62) suggests that psychological restoration is needed in the development of quintessential African leadership for socio-political transformation. He further explains that such restoration can help to combat the negative consequences of the bleak history of the continent on its people, including their leaders.

Through psychological restoration the re-evaluation of African culture can be encouraged and the confidence of despondent Africans in their own selves as dignified human beings can be stimulated. African traditional values can also be taught and their positive contributions highlighted; African traditional anti-values can equally be depreciated and discouraged here.

\section{Promoting re-decolonisation and resisting re-colonisation}

Explaining mind decolonisation as an essential concern of African Renaissance, Diop (1999) observes:

In this age of science and technology, the essential issue at stake
in the African Renaissance is that of devising ways and means to
revert this age-old regressive trend and to regain the historical
initiative as a people, in order to secure Africa's reconstruction
and development on the basis of the vital needs and legitimate
hopes of the majority of Africans. Now, after political liberation
the priority is to decolonise the mind, in so far as any renaissance
process first starts with a degree of cultural awakening. (pp. 5-6)

Long after political decolonisation, a lot of Africans remain mentally colonised in various ways as indicated by Francis 
Fanon earlier on. The decolonisation of their mind can empower them for effective self-transformation to be able to resist re-colonisation and contribute to solid sociopolitical transformation. Linked to the idea of psychological restoration of Africans and their cultural stimulation is the understanding that slave trade, colonisation and neocolonisation are detestable experiences that can no longer be allowed. Supportively, Mentan (2007) observes:

The present crisis in Africa is the legacy of centuries of pillage, beginning with the slave trade and continuing through the colonial conquest and partition carried out by British, French, Belgian, Italian and German imperialism. (p. 199)

Restricting negatives of colonisation to leadership, Gordon (2002) concludes:

The lingering effects of its seventy-five years of domination are manifested most profoundly in Africa's current leadership problem, which remains a malignant (central) feature of the general African crisis. (p. 1)

And the best place to start with such preparation is amongst African leaders who have been used either in slave trade or neo-colonisation and who can be used again for recolonisation. Prevention being cheaper and easier than remedy, African Renaissance philosophers and/or activists regularly raise awareness about these undesirable and bitter events and their consequences through writings and public speeches. Some of them have even started warning the public against a re-colonisation of the continent and why this move should be prevented. One of those is Thabo Mbeki who not only speaks against colonial ills on a regular basis, but also publicly condemns the continual neo-colonial activities in Africa (Mbeki 2011:5-6). Based on at least two Western issues, he insists that Africans must beware of the Western project of re-colonising Africa and consistently work against the shameful project. He first indicates that the British commentator, Richard Gott wrote in the London New Statesman Magazine published on 15 January 2001 stating:

There is a growing belief, not least within the ranks of latter-day new Labour missionaries, that appears to favour the reconquest of Africa. ... The new missionaries are much like the old ones, an advance guard preparing the way for military and economic conquest. (Gott 2001:n.p.)

Then explaining further, he observes that 7 years later, on April 19, 2008 The Times (London) published an article by Matthew Parris entitled 'The new scramble for Africa begins', which drew attention to the global demand for the immense African natural resources, and said:

Fifty years ago the decolonisation of Africa began. The next half-century may see the continent recolonised. But the new imperialism will be less benign. Great powers aren't interested in administering wild places any more, still less in settling them: just raping them. Black gangster governments sponsored by selfinterested Asian or Western powers could become the central story in 21stcentury African history. He ultimately suggests that proxy wars for democracy waged in situations like that of Ivory Coast and Libya may be a concrete warning to Africans for what can happen. (Mbeki 2012:14-15)
The current situation in Democratic Republic of the Congo may be one of those cases where proxy wars are fought and won in the name of a democracy which, in reality, is the concern of none of those who claim to fight for it; then a fake democratic leadership team is supported into power and the natural resources of the land are snatched away to the West with the help of accomplice Africans (Nzongola-Ntalaja 2007:232-233). These are also situations where African churches and the global church can come together and play some prophetic role towards political leaders against recolonisation.

Understanding one's community, its history, how it works and how it is led pertains to political theology (Mutombo-Mukendi 2011:17, 19) and is an indication of political conversion. Dorr (1990:14-15) explains political conversion as the conversion of someone's mind to political responsibility. So, being politically converted involves the understanding of how one's society is structured and how it works, and the commitment to correcting injustices and to replacing unjust structures with equitable ones. Leading their people, especially Christians, to political conversion as well as developing spiritual leaders constitutes the responsibility of church leaders. Training and developing people who can contribute to an effective socio-political transformation of communities through intercession and other transformative activities are also their responsibility. This political conversion is important for Africans since it assists in understanding socio-political problems of their communities and their causes to be able to efficiently work for the needed transformation.

\section{Conclusion}

Leadership within any organisation is a very important aspect which requires serious consideration, for organisations and communities begin with and exist thanks to their leaders; they fall or rise, thrive or fail, because they have good or poor leaders. To build his church - an organisation that can be said to be globalising and multinational and that has powerfully influenced cultures, communities and individuals - Jesus Christ started by selecting and developing the leadership of this organisation. This example can be a positive inspiration for African organisations, communities and nations, to really secure a better living for all. This article intends to contribute to the development of effective transformational leadership by explaining what such leadership consists of, what its qualities are, and how it can positively contribute to solid transformation of the continent. It equally encourages Africans to be mindful of their responsibility to work for effective transformational leadership. The article has therefore provided essential steps that can securely lead to the development of such important leadership.

\section{Acknowledgements Competing interests}

The authors declare that they have no financial or personal relationship(s) that may have inappropriately influenced them in writing this article. 


\section{Authors' contributions}

K.M. (University of Stellenbosch) was the project leader. A.K.B. (University of South Africa) made conceptual contributions.

\section{References}

Banda, Z.J., 2010, 'African Renaissance and missiology: A perspective from mission praxis', PhD thesis, UNISA, Pretoria.

Banza, K., 2003, 'Empowering African elites for Christian praxis: The experience of the International Church of Pretoria', Master's thesis, UNISA, Pretoria.

Barna, G., 2001, Growing true disciples: New strategies for producing genuine followers of Christ, Waterbrook, Colorado Springs.

Burns, J.M., 1978, Leadership, Harper \& Row, New York.

Fanon, F., 1967, The wretched of the earth, transl. C. Parrington, Penguin Books, Harmondsworth.

Ciulla, J., 1996, 'Ethics, chaos, and the demand for good leaders', in P.S. Temes (ed.) Teaching leadership, pp. 181-201, Peter Lang, New York.

De Beer, S. \& Venter, D., 1998, Doing theology in the city - Workshop One, Institute for Urban Ministry, Pretoria.

Diop, D., 1999, 'Africa: Mankind's past and future', in M.W. Makgoba (ed.), African Renaissance: The new struggle, pp. 3-9, Mafube \& Tafelberg, Cape Town.

Dorr, D., 1990, Spirituality and justice, Orbis books, New York.

Gifford, P., 1998, African Christianity: Its public role, Indiana University Press, Indianapolis.

Gordon, J.U., 2002, African leadership in the twentieth century: An enduring experiment in democracy, University Press of America, Lanham.

Gott, R., 2001, London New Statesman Magazine, 15 January, n.p.

Greenleaf, R.K., 2002, Servant leadership: A journey into the nature of legitimate power and greatness, Paulist Press, Mahwah, NJ.

Halverson, R.C., 1982, 'Bringing nations to its knees', Christianity Today 26, 23

Hoppers, C.A.O., Moja, T. \& Mda, T., 1999, 'Making this our last passive moment: The way forward', in M.W. Makgoba (ed.), African Renaissance: The new struggle, pp. 233-239, Mafube \& Tafelberg, Cape Town.

Kalemba, M., 2011, 'The church task regarding leadership crisis in sub-Saharan Africa', paper presented at Africa Leadership Forum, Nairby, Kenya, 04-11th November.

Kä Mäna, K., 2005, 'La mission de l'église africaine: Pour une nouvelle éthique mondiale et une civilisation de l'espérance', Cipcre-Ceros, Yaoundé.

Kretzschmar, L., 2006, 'The Indispensability of spiritual formation for Christian leaders', Missionalia 34(2/3), 338-361.

Linthicum, R.C., 1991, Empowering the poor: Community organizing among the city's 'Rag, tag and bobtail, Marc, Monrovia. PMCid:PMC1656321

Maxwell, J.C., 2007, The Maxwell leadership Bible, Thomas Nelson, Nashville.

Mathafena, R.B., 2007, 'Investigating the effectiveness of the leadership development intervention in changing leadership practices in Markham', Magister Technologiae thesis, UNISA, Pretoria.

Mbeki, T., 1998, Africa - The time has come, Tafelberg \& Mafuba, Cape Town.

Mbeki, T., 2003, Africa-Define yourself, Tafelberg \& Mafuba, Cape Town.

Mbeki, T., 2011, 'What the world got wrong in Côte d'Ivoire. Why is the United Nations entrenching former colonial powers on our continent? Africa can and should tak the lead in resolving their own disputes', US-based Magazine Policy Magazine, 29 Avril 2011, viewed 28 June 2011, from http://www.foreignpolicy.com
Mbeki, T., 2012, 'Reflections on peacemaking, state sovereignty and democratic governance in Africa', Speech given to the Community Law Centre, at the Dullah Omar eighth Memorial Lecture, February 16, 2012, University of Western Cape, Omar

Mbigi, L., 2005, The spirit of African leadership, Knores, Johannesburg.

McDowell, S. \& Beliles, M., 2008, Liberating the nations: Biblical principles of government, education, economics and politics, Providence Foundation, Charlottesville.

Mentan, T., 2007, With neither guns nor bullets: Recolonisation of Africa today, Globa Media Publications, New Delhi.

Mihai, J., 2009, 'Spirituality and leadership: Would an organization benefit from spiritual leaders?', Spirituality in Higher Education Newsletter 1(4), 1-2.

Mogo, M.G., 1999, 'African culture in education for sustainable development', in M.W. Makgoba (ed.), African Renaissance: The new struggle, Mafube \& Tafelberg, Cape Town.

Mugambi, J.N.K., 1995, From liberation to reconstruction: African Christian theology after the Cold War, East African Educational Publishers Ltd, Nairobi.

Mulemfo, M.M., 2001, Thabo Mbeki and the African Renaissance, Good wood, Western Cape.

Mutombo-Mukendi, F., 2011, La théologie politique africaine: Exégèse et histoire, L'Harmattan, Paris.

Nzongola-Ntalaja, G., 2007, The Congo from Leopold to Kabila: A people's history, Zed Books, London.

Okumu, W.A.J., 2002, The African Renaissance: History, significance and strategy, Africa World Press, Trenton.

Parris, M., 2008, 'The new scramble for Africa begins', The Times, 19 April, n.p.

Perkins, J., 2004, Confessions of an economic hit man, Berrett-Koehler Publishers, San Francisco.

Prozesky, M., 1990, Christianity in South Africa, Southern Book Publishers, Pietermaritzburg.

Ramasamy, A.J., 2004, 'A radical Evangelical-Pentecostal response to the African Renaissance in terms of selected Christian values', Master's thesis, UNISA, Pretoria.

Renou, X., 2001, 'A Major obstacle to African unity: The new Franco-American Cold War on the continent', in E. Maloka (ed.), A United States of Africa?, pp. 419-444, Africa Institute of South Africa, Pretoria.

Rodney, W., 1982, How Europe underdeveloped Africa, Howard University Press, Washington, DC. PMCid:PMC2580184

Rotberg, R.I., 2004, 'Leadership in Africa', Chimera 2(2), 9-12.

Senghor, L.S., 1988, Ce que je crois, Grasset, Paris.

Smith, D.P., 1996, Empowering ministry: Ways to grow in effectiveness, Westminster John Knox Press, Louisville.

Thomson, J., 1996, Equipped for change: Studies in the Pastoral Epistles, A.C.U. Press, Abilene.

Van der Walt, B.J., 2001, Transformation by the renewing of your mind, Printing Things, Potchefstroom.

Van Rensburg, G., 2007, The leadership challenge in Africa: A framework for African Renaissance leaders, Van Schaik, Pretoria.

Walters, J.D., 1987, The art of supportive leadership: A practical guide for people in position of responsibility, Crystal Clarity Publishers, Nevada City.

Wellman, W., Perkins, G. \& Wellman, N., 2009, 'Educational leadership: The relationship between spirituality and leadership practices', Spirituality in Higher Education Newsletter 7, 1-6.

Williams, R.P.B., 2006, 'Towards a strategic transcultural model of leadership that enhances koinonia in urban Southern Africa (Synthesising a multicultural mode of leadership that transcends the socio-political barriers within the cities of Southern Africa)', Unpublished doctoral thesis, University of Pretoria, Pretoria. 